\title{
An Analytical Study on the Impact of Fluctuating Oil Prices on OPEC Economies
}

\author{
Indrani Hazarika
}

\begin{abstract}
The present study is undertaken to analyze the impact of changing oil prices on macroeconomic factors of OPEC economy which constitutes eighty one percent of the world proven crude oil reserves and has forty percent market share. Brent Crude Oil Spot Price FOB (Dollars per barrel) is the independent variable which is regressed against the dependent variables: GDP at current market price, exports, current account and exchange rate from 2007 to 2014. Though decline in oil prices has significant macroeconomic, financial and policy implications, the results of the present study states that changes in oil prices do not significantly impact the economic indicators of OPEC economies as lower oil prices reduce energy costs and generates changes in real income benefitting oil importers. Increase in oil prices have been followed by rising inflation and recessions in many countries.
\end{abstract}

Index Terms-Crude Oil, OPEC, macroeconomic factors, fluctuating.

\section{INTRODUCTION}

Crude oil is a mixture of hydrocarbons that exist in a liquid phase in natural underground reservoirs and impacts economic development, social equality, environment and peace. Like prices of other commodities the price of crude oil experiences wide fluctuations in times of shortage or oversupply. Oil prices shocks have been held responsible for changes in monetary policy, far-reaching labor market adjustments, and for changes in energy technologies.

\section{HISTORY OF CRUDE OIL PRICES}

The history of oil prices (see Table I and Fig. 1) dates back to 152 years of economic and political events that shaped the price, wars, economy, domestic policy, Organization of the petroleum exporting countries (OPEC) and price controls . Oil future contracts traditionally have been used by oil market participants to lock the price at which crude oil is to be bought and sold at a future date [1].

Oil prices dropped sharply in the second half of 2014 by 40 percent when it was $\$ 115$ a barrel bringing an end to the four year period of relative price stability. Oil prices are expected to remain low in 2015 and increase marginally in 2016. The causes of sharp decline can be attributed to recent developments in global oil markets that have occurred against a long term trend of greater than anticipated supply and less than anticipated demand, downward trend of global oil demand, slow economic growth in 2015 [2]. US dollar

Manuscript received March 3, 2015; revised May 26, 2015.

Indrani Hazarika is with Higher Colleges of Technology-Dubai Women's Campus, Dubai (e-mail: indrani.hazarika@ hct.ac.ae). appreciation, changes in OPEC objectives, geo political situation in Libya and Iraq the two main oil producers that has not affected their output. America has become the world's largest oil producer. Though it does not export crude oil, it now imports much less, creating a lot of spare supply.

TABLE I: HISTORY OF CRUDE OIL PRICE FLUCTUATIONS
\begin{tabular}{|c|c|}
\hline Year & Price Range in USD per barrel \\
\hline $1948-1970$ & $\$ 2.5-\$ 3$ \\
\hline $1974-1978$ & $\$ 12.52-\$ 14.57$ \\
\hline $1979-1980$ & $\$ 14-\$ 35$ \\
\hline $1981-1986$ & $\$ 10-\$ 15$ \\
\hline $1990-1991$ & $\$ 20-\$ 25$ \\
\hline $1997-1998$ & $\$ 17-\$ 18$ \\
\hline $2000-2003$ & $\$ 30$ \\
\hline $2004-2008$ & $\$ 41-\$ 140$ \\
\hline $2009-2013$ & $\$ 61-\$ 90$ \\
\hline
\end{tabular}

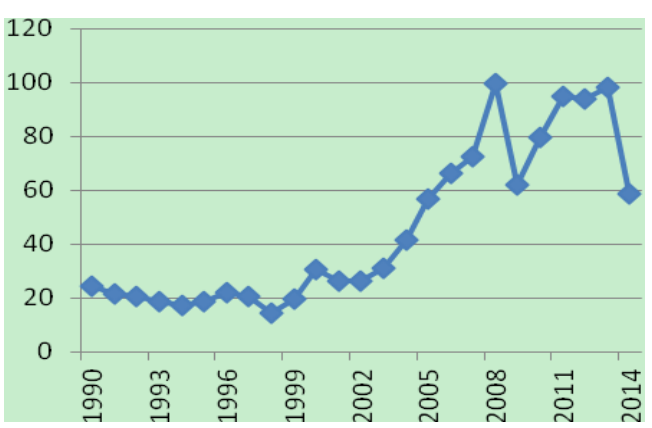

Fig. 1. Trend of crude oil prices (spot price FOB USD per barrel) from 1990 to 2014 .

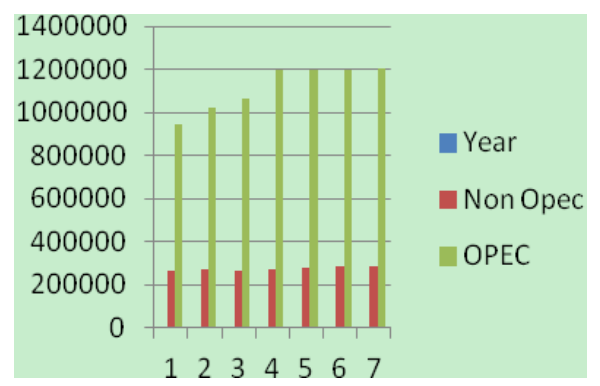

Fig. 2. World proven crude oil reserves in (million barrels) from 2007-2013.

\section{ORGANIZATION OF THE PETROLEUM EXPORTING COUNTRIES (OPEC)}

OPEC was established in 1960 with five founding members: Iran, Iraq, Kuwait, Saudi Arabia and Venezuela and presently stands with twelve member countries. According to 2013 estimates, almost $81 \%$ of the world's proven oil reserves are located in OPEC Member Countries, with the bulk of OPEC oil reserves in the Middle East, amounting to $66 \%$ of the OPEC total (see Fig. 2 and Fig. 3). The role of OPEC is to coordinate and unify the petroleum policies of its member 
countries and ensure the stabilization of oil markets in order to secure an efficient, economic and regular supply of petroleum to consumers, a steady income to producers and a fair return on capital for those investing in the petroleum industry. OPEC's proven oil reserves currently stand at $1,206.17$ billion barrels at the end of 2013 .

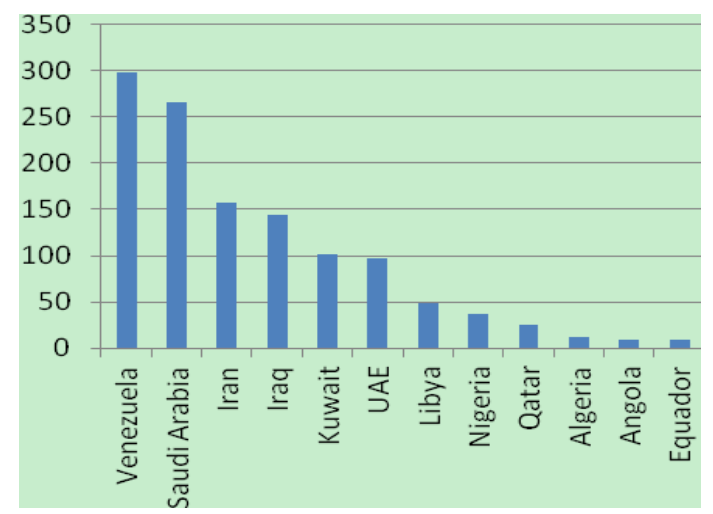

Fig. 3. Crude oil reserves in OPEC member countries as on 2013 in billion barrels.

\section{OBJECTIVE OF THE STUDY}

The present study is undertaken to analyze the impact of changing oil prices on the macro economic factors of OPEC member countries which produce about 40 percent of the world's crude oil and OPEC's oil exports represent about 60 percent of the total petroleum traded internationally. Because of this market share, OPEC's actions can, and do, influence international oil prices.

\section{LITERATURE REVIEW}

Hamilton (1983) demonstrates that historic correlation between oil price increase and economic recession is not a statistical coincidence. The existence of a negative relationship between oil prices and macroeconomic activity has become widely accepted since Hamilton's (1983 work) indicating that oil price increase reduced US output growth from 1948-1980 [3]. In 1986, Gisser and Goodwin indicated for the analyzed period from 1961 to 1982 that the oil price hadn't lost its potential to predict GNP growth [4]. Mork (1989) shows an even stronger negative correlation between oil price increase and output growth than Hamilton [5]. Relying on the fact that real shocks are the primary causes of exchange rate fluctuations as confirmed by Clarida and Gali (1994), the author considers the long-run nexus between oil price and real exchange rate using a monthly panel data for G7 countries [6]. Ferderer (1996) observed during 1970-1990 the fact that volatility and oil price changes have a stronger and more significant impact on economic activity than monetary policy variables [7]. Hooker (1996) confirmed [8]Hamilton's results and demonstrated for the period 1948-72 that the oil price level and its changes do exert influence on GDP growth [9]. Hamilton (2000) stressed that previous studies assumed linearity between the log of real GDP and $\log$ of real oil prices [10]. Abeysinghe (2001) revealed that open economies experience both direct and indirect impacts of oil prices on GDP growth whose magnitude depends on whether the economy is a net oil importer or exporter [11]. Balke and Yucel (2002) give a similar explanation of the asymmetric effects of oil price shocks have on macroeconomic activity [12]. Nnanna and Mashi (2003) investigates oil price shocks effect on the macroeconomic performance of Nigeria from 1980-2007 via VAR model using different asymmetric transformations for oil price variable and found significant positive effect of oil price increase, than adverse effect of oil price decrease on real GDP [13]. Authors such as Hamilton (1983), Jimmenez-Rodriguez and Sanchez (2005), Cunado and Perez de Gracia (2005) among others have investigated the interdependence between oil prices and GDP in the major developed countries [14]. Among others, Rebeca and Sanchez (2004 and 2009), Nung (2005), Sandrine and Mignon (2008), Jacobs (2009) and Yazid Dissou (2010) document that macroeconomic variables are significantly sensitive to oil price increases and volatility.

\section{RESEARCH METHODOLOGY}

The study is based on the impact of US Brent Crude Oil Spot FOB Price from 2007 to 2014 and its impact on macroeconomic factors of OPEC economies considering global crisis and post global crisis period. Following existing literature the focus is on four macroeconomic variables: Nominal foreign exchange rate, GDP, Current Account, Exports and average world price of oil which were not previously tested on OPEC economies.

\section{A. Research Questions}

The research question addressed is whether the fluctuation in oil prices which is an independent variable affects the dependent variable which in the present study is the macroeconomic indicators.

\section{B. Research Design}

The study is based on secondary data available on the Annual Bulletin of OPEC and Spot Crude Oil Prices in dollars per barrel, collected from independent statistics and analysis of US energy Information and Administration from 2007 to 2014 and Annual Bulletin and Press Release of OPEC.

\section{Sample Design}

For the present study macroeconomic data has been collected for the twelve OPEC member countries and the Brent Crude Oil Spot Price FOB per barrel.

\section{Data Analysis}

The data has been analyzed with the help of Data Analysis in Excel using Significance $F$ and $R$ square in simple regression analysis as the independent variable is the crude oil price and macroeconomic indicators are dependent variables. The following model is repeatedly used for the study to establish the relation between the dependent variables and single independent variable for 12 observations.

Equation: $Y=\beta 0+\beta 1 X 1+\mu$ where independent variable $X$ is the crude oil price and dependent variable $Y$ is the economic indicator and $\mu$ represent errors. 


\section{FINDINGS}

The correlation coefficient as shown in Table II between the independent variable crude oil and dependent variables are all less than 0.5 except for few countries where it is greater than 0.5 with reference to exports and current account.

TABLE II: CORRELATION COEFFICIENT CRUDE OIL PRICE AND ECONOMIC INDICATORS

\begin{tabular}{|c|c|c|c|c|}
\hline \multicolumn{5}{|c|}{ INDICATORS } \\
\hline Country & GDP & Exports & $\begin{array}{c}\text { Current } \\
\text { Account }\end{array}$ & $\begin{array}{c}\text { Exchange } \\
\text { Rate }\end{array}$ \\
\hline Algeria & 0.4 & 0.8 & 0.4 & -0.4 \\
\hline Angola & 0.2 & 0.6 & 0.4 & -0.06 \\
\hline Ecuador & 0.19 & 0.6 & 0.02 & NA \\
\hline Iran & 0.33 & 0.5 & 0.3 & -0.3 \\
\hline Iraq & 0.19 & 0.4 & 0.7 & -0.19 \\
\hline Kuwait & 0.4 & 0.9 & 0.5 & -0.6 \\
\hline Libya & 0.18 & -0.07 & 0.3 & -0.4 \\
\hline Nigeria & 0.07 & 0.2 & 0.4 & -0.3 \\
\hline Qatar & 0.2 & 0.2 & 0.2 & NA \\
\hline Saudi & 0.2 & 0.6 & 0.5 & NA \\
\hline UAE & 0.2 & 0.14 & 0.2 & NA \\
\hline Venezuela & 0.13 & 0.7 & 0.5 & 0.05 \\
\hline
\end{tabular}

\section{Regression Output}

The regression results in Table III shows that $\mathrm{R}$ Squared is less than 0.2 (Confidence Level 95\%) with respect to all dependent variables: GDP, Exchange Rate, Current Account and Exports except for Kuwait and Algeria with reference to exports. Less than 0.2 percent changes in the dependent variables are brought by the independent variable. In the regression output Significance F is greater than 0.05 for all the dependent variables except for Algeria with reference to exports. Rotemberg and Woodford (1996), Hamilton (2000) and Hooker (2006) mentioned in their findings that historic GDP decreased by $0.6 \%, 1.4 \%$ and $2.5 \%$ during the period of study from 19481972 and $1948-1980$ after a 10\% oil price increase [15]. Oleg Zaytsev (2010) states that abrupt increase in the price of oil has no negative effect on real GDP of Ukraine [16]. Findings reveal that there is a statistically significant influence of oil price shocks on macroeconomic activities in the G-7 (Cologni and Manera, 2008; Kilian, 2009), and Norway (Jimmenez-Rodriguez and Sanchez, 2005) and Asian countries (Cunado and Perez deGracia, 2005. Asymmetry in effects has been observed, as oil price increases have a clear negative impact on economic growth while oil price declines don't affect economic activity significantly which was confirmed by Mork, Olsen and Mysen (1994) for other OECD (Organization for Economic Cooperation and Development) countries [17].

TABLE III: REGRESSION RESULTS

\begin{tabular}{|c|c|c|c|c|c|c|c|c|}
\hline \multirow{2}{*}{ Countries } & \multicolumn{2}{|c|}{ GDP } & \multicolumn{2}{c|}{ Exports } & \multicolumn{2}{c|}{ Current Account } & \multicolumn{2}{|c|}{ Exchange Rate } \\
\hline OPEC & $R^{2}$ & $F$ & $R^{2}$ & $F$ & $R^{2}$ & $F$ & $R^{2}$ & $F$ \\
\hline Algeria & 0.12 & 0.44 & 0.6 & 0.02 & 0.4 & 0.10 & 0.19 & 0.31 \\
\hline Angola & 0.009 & 0.83 & 0.4 & 0.12 & 0.2 & 0.2 & 0.04 & 0.6 \\
\hline Ecuador & 0.008 & 0.84 & 0.3 & 0.14 & 0.09 & 0.5 & 1 & NA \\
\hline Iran & 0.06 & 0.5 & 0.3 & 0.17 & 0.17 & 0.3 & 0.17 & 0.3 \\
\hline Iraq & 0.01 & 0.79 & 0.13 & 0.4 & 0.6 & 0.03 & 0.02 & 0.7 \\
\hline Kuwait & 0.15 & 0.3 & 0.8 & 0.005 & 0.26 & 0.24 & 0.3 & 0.12 \\
\hline Libya & 0.02 & 0.73 & 0.005 & 0.8 & 0.25 & 0.24 & 0.18 & 0.3 \\
\hline Nigeria & 0.0001 & 0.97 & 0.05 & 0.6 & 0.4 & 0.12 & 0.3 & 0.2 \\
\hline Qatar & 0.02 & 0.7 & 0.012 & 0.8 & 0.04 & 0.6 & NA & NA \\
\hline Saudi & 0.03 & 0.6 & 0.3 & 0.17 & 0.3 & 0.16 & NA & NA \\
\hline UAE & 0.02 & 0.7 & 0.003 & 0.9 & 0.03 & 0.6 & NA & NA \\
\hline Venezuela & 0.01 & 0.8 & 0.5 & 0.06 & 0.3 & 0.19 & 0.00 & 0.9 \\
\hline
\end{tabular}

\section{CONCLUSION}

The existing literature on oil price fluctuations and macroeconomic factors states that there is a statistically significant influence of oil price shocks on macroeconomic activities in Norway, G-7 and Asian countries and oil price shocks and real exchange rates of G-7 countries. Historic GDP decreased by around $2 \%$ after $10 \%$ increase in oil price. When oil price increases there is a clear negative impact on economic growth while oil price declines don't affect economic activity significantly. But the most important findings according to the present study is fluctuating oil prices do not impact significantly the macroeconomic indicators of OPEC economies with $81 \%$ of the world's proven reserves, producing $40 \%$ of world's crude oil and OPEC's oil exports represents $60 \%$ of the total petroleum traded internationally. Abrupt changes in oil prices do not affect the GDP of OPEC economy, rather impact of changes in an oil economy occurs through cost and demand.

\section{REFERENCES}

[1] L. Kilian and D. Murphy, "The role of inventories and speculative trading in the global market for crude oil," Mimeo, Department of Economics, 2011

[2] J. Baffes, A. Kose, F. Ohnsorge, and M. Stocker, "Understanding the plunge in oil prices: Sources and implications," Global Economic Prospects, pp. 155-168, January 2015.

[3] J. Hamilton, "Oil and macroeconomy since World War II," Journal of Political Economy, vol. 91, pp. 228-248, 1983.

[4] M.Gisser and T. Goodwin, "Crude oil and the macroeconomy: Tests of some popular notions," J. Money Credit Banking, vol. 18 no. 1, pp. 95-103, 1986

[5] K. Mork, "Oil and the macroeconomy. When prices go up and down: An extension of Hamilton's results," Journal of Political Economy, vol. 97 no. 51,1989 .

[6] R. Clarida and J. Gali, "Sources of real exchange rate fluctuations How important are nominal shocks?" in Proc. Carnegie-Rochester Conference Series on Public Policy, 1994, vol. 41, pp. 1-56.

[7] J. Ferderer, "Oil price volatility and the macroeconomy," Journal of Macroeconomics, vol. 18, no. 1, pp. 1-26, 1996.

[8] M. Hooker, "What happened to the oil price macroeconomy relationship?" Journal of Monetary Economics, vol. 38, pp. 195 -213, 1996. 
[9] J. Hamilton, "What is an oil shock?" NBER Working Paper 7755 , 2000.

[10] J. Hamilton, "This is what happened to the oil price macroeconomy relationship," Journal of Monetary Economics, vol. 38, pp. 195-213, 1996.

[11] T. Abeysinghe, "Estimation of direct and indirect impact of oil price on growth," Economic Letters, vol. 73, pp. 147-153, 2001.

[12] N. Balke, S. Brown, and M. Yucel, "Oil prices shocks and the U.S. economy: Where does the asymetry originate," The Energy Journal, vol. 23 , no. 3, pp. 27-52, 2002

[13] O. Nnanna and I. Masha, "Oil price fluctuation, macroeconomic behaviour and policy response in Nigeria: A VAR Specification," West African Journal of Monetary and Economic Integration, WAMI Publication, 2003.

[14] J. R. Rodriguez and M. Sanchez, "Oil price shocks and real GDP growth: Empirical evidence for some OECD countries," Applied Economics, vol. 37, no. 2, pp. 201-228, 2005.

[15] J. Rotemberg and M. Woodford, "Imperfect competition and the effects of energy price increases on economic activity," Journal of Money Credit and Banking, vol. 28, no. 4, pp. 550-577, 1996.

[16] O. Zaytsev, "The impact of oil price changes on the macroeconomic performance of Ukraine," Master Degree Dissertation, Department of Economics, Kyiv School of Economics, 2010.

[17] K. Mork, O. Olsen, and H. Mysen, "Macroeconomic responses to oil price increases and decreases in OECD countries," Energy Journal vol. 15 , no. 4, pp. 19-35, 1994.

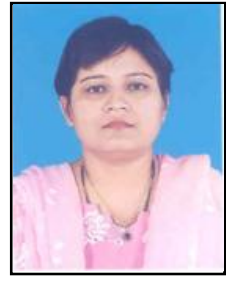

Indrani Hazarika was born on August 31, 1972 in Guwahati, Assam, India. She obtained the Ph.D. degree in the area of taxation from Gauhati University, Guwahati, India in 2003, and the master degree in discipline commerce with specialization in finance, accountancy and taxation from Gauhati University, Guwahati in 1996. Her major field of study is in accounting and finance.

She is currently working as a business faculty member at Higher Colleges of Technology (HCT), Dubai Women's Campus and she is also the chair of Accounting Curriculum Committee at HCT. Prior to joining at HCT, she was the Training and Research manager in Dubai Gold and Commodities Exchange. Before relocating to Dubai she served as a faculty member of MBA, BBA \& Commerce in JVIMS, Jamnagar, Gujarat, India from 1999 to 2006 and was also a visiting faculty member at All India Management Association (AIMA), Jamnagar Centre. Prior to joining Gauhati Commerce College as a lecturer, she was a research scholar in Gauhati University carrying out her research work and received UGC grant for doing research. Her current and previous research interests include oil Prices causes and effects on airline industry and oil companies, IFRS, audit reengineering, profitability analysis of banks, revenue recognition principles with reference to real estate companies, fair value accounting, tax evasion, financial reporting, earnings quality, cost control and cost reduction, EVA and MVA. 